\title{
NATIONAL LEAGUE OF CITIES V. USERY TO EEOC $V$. WYOMING: EVOLUTION OF A BALANCING APPROACH TO TENTH AMENDMENT ANALYSIS
}

In National League of Cities $v$. Usery, ${ }^{1}$ the Supreme Court held that Congress exceeds its power under the commerce clause if it enacts legislation directed at functions essential to state sovereignty, because the tenth amendment ${ }^{2}$ reserves to the states plenary authority to structure integral operations in areas of traditional governmental functions. ${ }^{3}$ The Usery decision, which, according to Justice Brennan, must have astounded scholars of the Constitution, ${ }^{4}$ seemed mitially to be the harbinger of a new era of federahism in which the states would be afforded mcreased freedom in managing their own affairs. Eight years later, however, in March of 1983, the Supreine Court severely restricted the scope of the Usery doctrine. It held in EEOC $v$. Wyoming, ${ }^{5}$ that the Age Discrimination in Employment Act ${ }^{6}$ (ADEA) as apphed to the states did not violate the tenth amendment. Justice Stevens suggested im his concurrence that $U$ sery be "placed in the same category as E. C. Knight, Hammer v. Dagenhart, and Carter v. Carter Coal-cases whose subsequent rejection is now universally regarded as proper."7

This note analyzes the tenth amendment doctrine that has emerged simce the Court's decision in Usery. It argues that EEOC $v$. Wyoming did not overrule $U_{\text {sery, }}$, but is consistent with a method of analysis that the Court has developed in cases simce Usery and that was implicit in that opinion. Part I of the note discusses Usery and demonstrates that the case contains not one but two tests for determining whether an act of Congress infringes on the powers

1. 426 U.S. 833 (1976).

2. "The powers not delegated to the United States by the Constitution, nor prohibited by it to the States, are reserved to the States respectively, or to the people." U.S. CoNST. amend. X.

3. Usery, 426 U.S. at 852 .

4. Id. at 862 (Brennan, J., dissenting).

5. 103 S. Ct. 1054,1064 (1983).

6. 29 U.S.C. $\$ \$ 621-634$ (1982).

7. EEOC v. Wyoming, 103 S. Ct. at 1067 (Stevens, J., concurring) (citing United States v. E. C. Knight Co., 156 U.S. 1 (1894); Hammer v. Dagenhart, 247 U.S. 251 (1918); Carter v. Carter Coal Co., 298 U.S. 238 (1936)). 
reserved to the states by the tenth amendment. ${ }^{8}$ The first test, which appears in Justice Rehnquist's opmion for the Court, provides that any infringement, no matter how minimal, upon a traditional state function essential to state sovereignty violates the tenth amendment.9 Justice Blackmun provided the second test in a brief concurring opmion. He advocated a weighing of federal and state concerns to determine whether federal legislation should give way to a state's tenth amendment claims. ${ }^{10}$

Part II of the note examines Hodel v. Virginia Surface Mining \& Reclamation Association ${ }^{11}$ and FERC v. Mississippi, ${ }^{12}$ Supreme Court cases that arose after Usery and presented tenth amendment questions. ${ }^{13}$ The note analyzes these cases and argues that they illustrate the Court's retreat from Justice Rehnquist's rigid per se test im Usery and its adoption of Justice Blackmun's balancing approach. Part III discusses EEOC v. Wyoming. ${ }^{14}$ It argues that because the Court considered the degree of impairment of an essential state function relevant to its determination of whether the ADEA was constitutional, the Court was actually using Justice Blackmun's balancing test. This interpretation suggests that, although the Court's acceptance of the balancing approach restricts the scope of the tenth amendment as understood by Justice Rehnquist, the heart of the Usery holding, that state sovereignty circumscribes the enumerated powers of the federal government, has survived and may be invoked in future cases, despite vehement criticism of the Usery holding by Justices Brennan and Stevens. ${ }^{15}$

\section{NATIONAL LEAGUE OF CITIES \%. USERY: REVITALIZING THE TENTH AMENDMENT}

Prior to 1976, the Supreme Court attached little significance to the tenth amendment. ${ }^{16}$ The Court read the amendment as providing only that those powers not delegated to the federal governinent were to be

8. See infra notes $18-33$ and accompanying text.

9. Usery, 426 U.S. at 852.

10. Usery, 426 U.S. at 856 (Blackmun, J., concurring).

11. 452 U.S. 264 (1981).

12. 456 U.S. 742 (1982).

13. See infra notes $34-61$ and accompanying text.

14. See infra notes $64-92$ and accoinpanying text.

15. See Usery, 426 U.S. at 862 (Brennan, J., dissenting); EEOC v. Wyoming, $103 \mathrm{~S}$. Ct. at 1067 (Stevens, J., concurring).

16. See, e.g., Gibbons v. Ogden, 22 U.S. (9 Wheat.) 1, 96 (1824) (holding that the tenth amendment does not limit congressional exercise of enumerated powers); McCulloch v. Maryland, 17 U.S. (4 Wheat.) 316, 404-07 (1819) (same); Martin v. Hunter's Lessee, 14 U.S. (1 Wheat.) 304, 322-24 (1816) (same). 
exercised by the states. The Court, in United States v. Darby, ${ }^{17}$ went so far as to describe the amendment as a "truism that all is retained which has not been surrendered." Under this view, states could not employ the tenth amendment to curtail congressional exercise of an enumerated power because the amendment was understood only to parcel to the states those powers that the Constitution had not delegated to Congress.

The Court's decision in National League of Cities v. Usery, however, transformed the tenth amendment into a limitation on the enumerated powers of Congress. In Usery, the Court reviewed the constitutionality of the 1974 amendments to the Fair Labor Standards $\operatorname{Act}^{18}$ (FLSA), which extended federal minimum-wage and maximumhour provisions to most state and municipal employees. Various organizations of states and municipalities had argued that, although the commerce clause empowered Congress to enact the amendments, they were nonetheless invalid because they intruded on the powers reserved to the states by the tenth amendment. These orgamizations noted that the Court had previously held that congressional "enactments which may be fully within the grant of legislative authority contamed in the Commerce Clause may nonetheless be found to offend against the right to trial by jury contained in the Sixth Amendment." 19

17. 312 U.S. 100, 124 (1941).

18. The Fair Labor Standards Act of 1938, 29 U.S.C. $\$ \S 201-219$ (1982), requires employers covered by the Act to pay their employees a minimum hourly wage and to pay them at the rate of one and one-half times their regular pay for hours worked in excess of 40 during a workweek. For a history of the Act, see Maryland v. Wirtz, 392 U.S. 183, 185-87 (1968). As origimally enacted, the Act expressly excluded states from its coverage: " 'Employer' includes any person acting directly or indirectly in the interest of an employer im relation to an employee but shall not include the United States or any State or political subdivision of a State . . ." The Fair Labor Standards Act of 1938, Pub. L. No. 75-718, §3(d), 52 Stat. 1060, 1060. Congress amended the Act in 1966 expressly to include within its coverage "enuployees of a State, or a political subdivision thereof, employed . . . in a hospital, institution or school." 29 U.S.C. \& 203(d) (1982). The Suprene Court subsequently concluded that Congress did not intend by this aniendment to exercise its power under the cominerce clause to lift the states' eleventh anendment imnunity against suit in a federal forum. Employees of the Dep't of Pub. Health \& Welfare v. Missouri, 411 U.S. 279, 285 (1973). In response to the Court's decision that the 1966 amendment did not subject the states to suit in federal court, Congress the next year expressly included states within the scope of the Act by amending the term "employer" to include "public agency." 29 U.S.C. \& 203 (1982). The Court did not reconsider the eleventh amendment issue in Usery, because it imvalidated the 1974 amendments on tenth amendment grounds. See Redish, Federal CourTs: CASES Comments \& QuesTIONS 554 (1983).

19. Usery, 426 U.S. at 841 . It is interesting to note that the political subdivisions of the states which brought suit in $U s e r y$ nuay claim the shelter of the tenth aniendment, but not of the eleventh amendment. Cf. Lincoln County v. Luning, 133 U.S. 529, 530 (1890) (a county is not part of a state for the purposes of the eleventh amendment). For a critical discussion of the dichotony, see generally Note, The Denial of Eleventh Amendment Immunity to Political Subdivisions of the States: An Unjustifed Strain on Federalism, 1979 Duke L.J. 1042. 
The Supreme Court held that the 1974 amendments were unconstitutional, but did so on slightly different grounds than the appellants had suggested. It held that Congress was without power under the commerce clause to enact legislation that would "displace the States' freedom to structure integral operations in areas of traditional governmental functions," 20 or would threaten a "State's 'ability to function effectively in a federal system." 21 It concluded that, because the amendinents to the FLSA threatened state autonomy, they violated the tenth amendment.22 The Court transformed the tenth amendinent froin a superfluity into an affirmative limitation on Congress's broad powers.

Although the Court made it clear that it read the tenth annendment as commanding that delegated powers may not be exercised so as to "override state sovereignty," ${ }^{23}$ the opinion contains many ambiguities. First, the Court determined that, to ensure protection of state sovereignty, no federal legislation could impinge upon an "essential state function."24 Justice Rehnquist, writing for the Court, provided no framework for identifying such essential state functions. ${ }^{25}$ Instead he offered a concededly incoinplete list of functions, includimg fire and pohice protection, sanitation, public health, and parks and recreation. ${ }^{26}$

20. Usery, 426 U.S. at 852.

21. Id. (quoting Fry v. United States, 421 U.S. 542, 547 n.7 (1974)).

22. Usery, 426 U.S. at 842 .

23. Id. at 845 .

24. Id.

25. A great deal of legal commentary focused on the ambiguity embedded in the phase. See, e.g., Kilbert \& Fort, National League of Cities v. Usery: Its Meaning and Impact, 45 Gro. WASH. L. Rev. 613, 615 n.23 (1977); La Pierre, The Political Safeguards of Federalism Redux: Intergov. ernmental Immunity and the States as Agents of the Nation, 60 WASH. U.L.Q. 779, 808-09 (1982); Lopach, The New Federalism of the Supreme Court: Diminished Expectations of National League of Cities, 43 MONT. L. REv. 181, 185 (1982); Matsuinoto, National League of Cities-From Footnote 10 Holding-State Immunity from Commerce Clause Regulation, 1977 ARIZ. ST. L.J. 35, 73 (1977); Tribe, Unraveling National League of Cities: The New Federalism and Affirmative Rights to Essential Government Services, 90 HARv. L. REv. 1065, 1104 (1977); see also Note, National League of Cities Crashes on Takeoff: Balancing Under the Commerce Clause, 68 GEo. L.J. 827, 829 (1980); Note, The Constitutional Limitations Upon Federal Regulation of Municipal Issuers, 51 ST. JoHN'S L. Rev. 565, 580 (1977); Note, National League of Cities v. Usery: Its Implications for the Equal Pay Act and the Age Discrimination in Employment Act, 10 U. MicH. J.L. REF. 239, 249 (1977); Note, Applying the Equal Pay Act to State and Local Governments: The Effect of National League of Cities v. Usery, 125 U. PA. L. Rev. 665, 674 (1977).

26. Usery, 426 U.S. at 851 . The ambiguity created by this lack of precision is reflected in conflicting lower court applications of the doctrine. See, e.g., Kramer v. New Castle Area Transit Auth., 677 F.2d 308, 310 (3d Cir. 1982) (public bus operations are not a traditional state function); Williams v. Eastside Mental Health Center, 669 F.2d 671, 680 (11th Cir. 1982) (inental health centers are not integral state functions) (dictum); United States v. Ohio Dep't of Highway Safety, 635 F.2d 1195, 1205 (6th Cir. 1980) (motor vehicle licensing is not a traditional state function); District of Columbia v. Train, 521 F.2d 971, 994 (D.C. Cir. 1975) (regulating inspection and inain- 
The Usery opinion is flawed by a second, more fundamental ambiguity. Even given the existence of a universally accepted, traditional state function, ${ }^{27}$ the opinion does not clarify when the Court would find that federal legislation improperly infringes on such state functions. Justice Rehnquist proposed a de minimis standard. According to his approach, once the Court identified a traditional state function essential to state sovereignty, any infringenent on that function would be impermissible. ${ }^{28}$ Justice Rehnquist considered both the degree of infringement and the federal government's reasons for the regulation to

tenance of motor vehicles is a traditional state function); Lefcourt v. Legal Aid Soc'y., 445 F.2d 1150, 1156-57 (2d Cir. 1971) (legal aid to poor may be an essential state function, but regulations involved did not affect such a function); San Antonio Metro. Transit Ass'n v. Donovan, 557 F. Supp. 445, 453-54 (W.D. Tex. 1983) (public bus operations are traditional state functions). San Antonio may provide the opportunity for another tenth amendment decision. The Suprenie Court noted probable jurisdiction, $104 \mathrm{~S}$. Ct. 64 (1983), and the case has been set for reargument in the 1984 Term. See also South Dakota v. Adams, 506 F. Supp. 50, 56 (C.D.S.D. 1980) (billboard regulation not a traditional state function); Jordan v. Mills, 473 F. Supp. 13, 18-19 (E.D. Mich. 1979) (decision to operate state-run stores for prison inmates is a traditional state function).

In Amersbach v. City of Cleveland, 598 F.2d 1033, 1037 (6th Cir. 1979), the court held that the operation of a municipally owned airport is a traditional state function. Noting that Usery provided no guidelines for determining a traditional state function, the court addressed four criteria:

(1) the government service or activity benefits the conmunity as a whole and is available to the public at hittle or no direct expense; (2) the service or activity is undertaken for the purpose of public service rather than for pecuniary gain; (3) government is the principal provider of the service or activity; and (4) government is particularly suited to provide the service or perform the activity because of a community wide need for the service or activity.

Id. at 1037. For the view that these four criteria extend far beyond the rationale of Usery and could lead to an erosion of Congress's power to legislate under the cominerce power, see Note, National League of Cities Crashes on Takeoff: Balancing Under the Commerce Clause, 68 GEo. L.J. 827, 849 (1980).

27. A clarification of these terms may possibly be gleaned by analogy fron the traditional and nontraditional distmctions made by the Court in tax cases. Even in these cases, however, where the state seeks immunity from a federal tax, the traditional state function doctrine is inadequately defined. See Kilberg \& Fort, supra note 25, at 615 n.23 (noting that the operation of liquor dispensaries by a state was held to be a nontraditional state function in South Carolina v. United States, 199 U.S. 437, 463 (1905), but that cotton ginning has been held to be a traditional state function, Frost v. Corporation Comm'n, 278 U.S. 515, 519 (1929)).

28. Usery, 426 U.S. at 845. Applying this standard to the facts of Usery, Justice Relinquist stated:

One undoubted attribute of state sovereignty is the States' power to determine the wages which shall be paid to those whom they employ in order to carry out their governmental functions, what hours those persons will work, and what conpensation will be provided where these employees niay be called upon to work overtime. The question we nuust resolve here, then, is whether these determinations are "functions essential to separate and independent existence," so that Congress may not abrogate the States' otherwise plenary authority to make them.

Id. at $845-46$ (quoting Lane County v. Oregon, 74 U.S. (7 Wall.) 71, 76 (1869)). 
be constitutionally irrelevant. ${ }^{29}$ Thus, the Usery Court stressed that "[w]e do not beheve particularized assessments of actual impact are crucial to resolution of the issue presented." 30

Justice Blackmun, although joining the majority opinion, filed a brief concurring opinion that suggested a much different analysis. He proposed a balancing approach that seemed to require courts to consider the degree of infringement of state sovereignty and the importance of the federal interest in their determination of tenth-amendment violations. ${ }^{31}$ Justice Blackmun's approach would not "outlaw federal power in areas such as environmental protection, where the federal interest is demonstrably greater [than the state's] and where state facility comphance with imposed federal standards would be essential." 32 Justice Blackmun did not explain how his balancing approach applied to the facts in Usery. It inay be presumed that he concurred in the Court's holding that the FLSA amendments offended the tenth amendment because he had balanced Congress's federal imterest in extending FLSA coverage to state government employees against the states's interest in settimg the wages for state employees, and found that the state interest should prevail.

Thus, Usery presented lower courts with two conflicting approaches for analyzing whether the tenth amendment imvalidated federal legislation. The ensuing confusion prompted one district court judge to comment that, because "Justice Blackmun's concurrence was the swing vote in the ultimate holdimg . . . , it is impossible to discern what test, if any, was estabhished for analyzing congressional exercises of power pursuant to the Commerce Clause." 33

29. Justice Rehnquist did agree, however, that in certain instances federal concerns were constitutionally relevant. For instance, in national emergencies, the tenth amendment would give way to "temporary enactments tailored to combat [such emergencies]." Id. at 853.

30. Id. at 851 .

31. Id. at 856 (Blackmun, J., concurring).

32. Id.

33. Tennessee v. Louisville \& N. R.R., 478 F. Supp. 199, 206 (M.D. Tex. 1979). This difficulty was shared by other lower courts. See, e.g., Amersbach v. City of Cleveland, 598 F.2d 1033, 1037 (6th Cir. 1979) (searching only for inpairnent of essential state function); $c f$. United States v. Ohio Dep't of Safety, 635 F.2d 1195, 1205 (6th Cir. 1980) (balancing federal interest in controlhing air pollution with state's interest in permitting non-complying vehicles to use public streets and highways in upholding Clean Air Act); Friends of the Earth v. Carey, 552 F.2d 25, 38 (2d Cir. 1979) (same); see also Lopach, supra note 25, at 185-86. 
II. The Importance of the Federal Interest: The Court's Adoption of THE First PRONG OF THE BaLANCING

\section{APPROACH}

Given the revolutionary nature of Usery, it is not surprising that the Supreme Court found it necessary to revise its relatively ambiguous test in two inajor cases decided prior to EEOC v. Wyoming. These cases suggest that Justice Blackmun's analysis of the strength of the federal interest and the degree of infringement of state interests have become the Court's preferred view. In Virginia Surface Mining ${ }^{34}$ and FERC v. Mississippi ${ }^{35}$ the Supreme Court considered the importance of the asserted federal concerns in its decision-a consideration that Justice Rehnquist had not deeined relevant in Usery.

\section{A. Formulating an Irrebutable Presumption: Virginia Surface Mining.}

In its 1981 decision in Virginia Surface Mining, ${ }^{36}$ the Court affirmed the constitutionahty of the Surface Mining Control and Reclamation Act of 1977.37 Certain Virginia coal producers and landowners ${ }^{38}$ challenged the Act's performance standards, which directed the Secretary of Interior to promulgate regulations establishing an interim regulatory program for surface coal mining. ${ }^{39}$ The Act required any state wishing to assuine perinanent regulatory authority over surface coal mining projects to submit a proposal to the Secretary for his approval. ${ }^{40}$ In its proposal, the state was obligated to demon-
34. 452 U.S. 264 (1981).
35. 456 U.S. 742 (1982).
36. 452 U.S. 264 (1981).
37. 30 U.S.C. $\S \S 1201-1328$ (1982)

The Surface Mining Act is designed to "establish a nationwide program to protect society and the environment froin the adverse effects of surface coal mining operations." 30 U.S.C. § 1202(a) (1982). It establishes a two-stage program for regulation, an interim regulating phase, and a permanent phase. 30 U.S.C. $\S 1251$ (1982). The interim phase requires immediate promulgation and federal enforcement of several of the Act's environmental protection performance standards. Under the permanent program, regulations are to be adopted for each state, requiring compliance with federal performance standards, with enforcement responsibility lying with either the state or federal government.

Regulations promulgated by the Secretary establishing the imterim regulatory program govern such areas as: (a) restoration of land after mining to its prior condition; (b) restoration of land to its approximate original contour; (c) segregation and preservation of topsoil; (d) minimization of disturbance to the hydrologic balance; (e) construction of coal mine waste piles used as dams and embankments; (f) revegetation of mined areas; and (g) soil disposal. 30 U.S.C. \& 1265(b) (1982).

38. Plaintiffs consisted of individual landowners, an association of coal-minimg operators, local mining companies, a town, and the Commonwealth of Virginia.

39. Virginia Surface Mining, 452 U.S. at 273.

40. 30 U.S.C. $\$ 1253$ (1982); see also Virginia Surface Mining, 452 U.S. at 270-72. 
strate that its legislature had enacted laws that implemented the environmental-protection standards provided in the Act. ${ }^{41}$ If a state failed to create or to enforce an acceptable program, it would become subject to a permanent federal program which the Secretary of Interior would develop and implement. ${ }^{42}$ In short, the Act required states to adopt regulations governing surface coal mining that were consistent with federal environmental policy, or face automatic preemption by federal law.

The coal producers and landowners challenged the Surface Mining Act on tenth amendment grounds. ${ }^{43}$ In deciding the tenth amendment question, the Supreme Court relied on a three-part test that it found implicit in Usery. The Court would consider federal legislation unconstitutional if: 1) it regulates a state as a state;44 2) it addresses "matters that are indisputably 'attributes of state sovereignty' "; and 3) enforcement of the statute would directly impair a state's ability to " 'structure integral operations in areas of traditional governmental functions." "45 The Court found the Act constitutional because it was directed at controlling the activity of private coal miners and thus did not constitute regulation of a state as a state. 46 Therefore, the Court did not proceed to the other elements of the three-part test.

In developing this test the Court restricted the potential scope of the Usery analysis. By requiring that the statute regulate the state as a state, the Court insulated from tenth-ainendment attack federal legisla-

41. 30 U.S.C. $\S 1253$ (1982).

42. 30 U.S.C. \& 1254 (1982).

43. The district court, relying on Usery, held that the Act violated the tenth amcndment. Virginia Surface Mining \& Reclamation Ass'n v. Andrus, 483 F. Supp. 425, 435 (W.D. Va. 1980). In so doing the court focused on whether the federal legislation infringed on a "traditional state function." Although Congress was regulating a private industry, the court found that the "power to adopt and enforce laws affecting the use of private, nonfederal land has traditionally and historically been within the police powers of the respective states." Id. at 433. Because the Act would displace the state's ability to make "essential decisions" in this area, id., the court held that the act improperly invaded areas of traditional governmental functions. Accord, Indiana v. Andrus, 501 F. Supp. 452, 464-65 (S.D. Ind. 1980), rev'd sub nom. Hodel v. Indiana, 452 U.S. 314, 317 (1980).

44. Virginia Surface Mining, 452 U.S. at 287. The Court's opinion in Usery contains dicta to the effect that statutes regulating the states as states are more intrusive of the sovereignty of the statcs than legislation that merely preempts state regulation over the private sector, 426 U.S. at 840, 844-45. Whether intentional or not, however, the Court did not establish a per se rule that legislation regulating private activity was beyond the scope of the tenth amendment. Thus, the requirement that a statute regulate a state as a state recited in Virginia Surface Mining constitutes a restriction upon a possible broad reading of Usery.

45. Virginia Surface Mining, 452 U.S. at 287-88 (quoting Usery, 426 U.S. at 852). The Court actually added a fourth part to the test when it notcd that there "are situations in which the nature of the federal imterest advanced may be such that it justifies state submission." 452 U.S. at 288 n.29.

46. Id. at 288. 
tion which regulated the private sector. It appeared to assume that the power of a state to regulate the private sector is never so important to that state as to be essential to its sovereignty. Yet this is a questionable assumption. As Professor Tribe has noted, although the provision of basic services is an important state function, "no less essential is the function of defining the scope of permissible conduct within a state's or municipality's borders tlirougl1 regulations aimed at private parties." 47 It is thus somewhat surprising that the Court took such a narrow view of a state's essential functions. A likely explanation is that the Court, in fashioning its tliree-part test, had begun to employ Justice Blackmun's balancing test. The Court appeared to be concerned with the consequences that classifying regulation of the private sectior as an essential state function would have on the federal government's ability to fulfill its legislative functions. If the tentli annendment were to protect from federal preemption all state regulation of the private sector, it would interfere witl a liost of federal statutes that the Court has long considered to be legitimate exercise of Congress's article I powers. This result, the Court noted, would be at odds with well-established precedent surrounding the supremacy clause. ${ }^{48}$ Had the Court chosen to use Justice Rehnquist's approach from Usery, it would not have used the first prong of its tliree-part test in Virginia Surface Mining. It would have considered only whether the state regulation of the private sector was an essential state function and, if so, whether the federal statute impaired the exercise of that function.

Instead, in Virginia Surface Mining, the Court engaged in a balancing approach; it looked at the general federal interest underlying the supremacy clause and balanced this against the state interest in regulating private entities. By adopting the first prong of its three-part test, the Court indicated that, in cases where Congress sought to regulate private parties, Congress's interest in ensuring the vitality of the supremacy clause is so compelling that it would always outweigh a

47. Tribe, supra note 25 , at 1074-75. This is the approach that was taken in the lower court. Virginia Surface Mining \& Reclamation Ass'n v. Andrus, 483 F. Supp. 425, 433 (W.D. Va. 1980).

48. The Court noted that:

A wealth of precedent attests to congressional authority to displace or pre-empt state laws regulating private activity affecting interstate coininerce when these laws conflict with federal law. . . . Although such congressional enactments obviously curtail or prohibit the States' prerogatives to make legislative choices respecting subjects the States may consider important, the Supreinacy Clause permits no other result.

Virginia Surface Mining, 452 U.S. at 290.

In response, one might argue in hight of Usery that because the tenth amendment is viewed as an affirmative limitation on Congress's enuinerated powers, the fact that an area of regulation is protected under the tenth anendment renders the congressional legislation unconstitutional; the supremacy clause thus is in no way affected. See id. 
state's tenth amendment claim. The Court, in essence, adopted a per se rule, protecting federal legislation froin tenth amendment challenges in cases involving regulation of the private sector. ${ }^{49}$

\section{B. Implicit Recognition of a Federal Interest: FERC v. Mississippi.}

The Court's 1982 decision in FERC v. Mississippi ${ }^{50}$ further buttresses the argument that the Court has adopted Justice Blackmun's balancing approach in its analysis of tenth amendment cases. In FERC v. Mississippi, the Court upheld the constitutionality of the Public Utility Regulatory Policies Act of 1978 (PURPA). ${ }^{51}$ Like the legislation in Virginia Surface Mining, this Act presented the states with the choice of adoptimg federal proposals or facing federal preemption. ${ }^{52}$ PURPA,

49. As a practical matter, the Court has always recognized the federal government's interest in uniformity in certain mining regulations. See id. at 268; see also Abrams, The Federal Surface Mining Control and Reclamation Act of 1977-First to Survive a Tenth Amendment Attack, 84 VA. L. REV. 1069, 1070-76 (1981). Justice Blackmun in Usery had noted the importance of uniformity in the area of environmental regulations. He considered this the type of federal concern that should justify certain inroads into state sovereignty. Usery, 426 U.S. at 826 (Blackmun, J., concurring).

50. 456 U.S. 742 (1982).

51. Pub. L. 95-617, 92 Stat. 3117 (codified at 16 U.S.C. $\$ \S 2601-2645$ (1982)) |hereinafter cited as PURPA]. The Act was signed into law on November 9, 1978 by President Carter. It was one of several pieces of legislation passed on the same day tailored to combat the nationwide energy crisis. They included the Energy Tax Act of 1978, Pub. L. 95-618, 92 Stat. 3174, (codified at scattered sections of 26 U.S.C. (1982)), the National Energy Conservation Policy Act of 1978, Pub. L. 95-619, 92 Stat. 3206 (codified at 42 U.S.C. $\$ \$ 8201-8226$ (1982)), the Powerplant and Industrial Fuel Use Act of 1978, Pub. L. 95-620, 92 Stat. 3289 (codified at 42 U.S.C. $\$ \$ 8301-8483$ (1982)), and the Natural Gas Policy Act of 1978, Pub. L. 95-621, 92 Stat. 3351 (codified at 15 U.S.C. $\S \S 717-719,3301-3416$ (1982)).

Congress enacted the PURPA using its authority under the commerce clause. Congress found that electric utilities were burdened with increasing costs and decreasing efficiency due in part to their reliance on oil and gas, and that this had a negative effect on rates to customers and on the econoiny as a whole. S. REP. No. 442, 95th Cong., 1st Sess. 9 (1977). Congress determined that conservation by electric utilities of oil and gas was necessary to reduce the country's dependence on foreign oil, to avoid a shortage of natural gas, and to control consumer costs.

52. Title I of PURPA requires each state regulatory authority to consider federal retail electric power rate standards, 16 U.S.C. $\$ \$ 2621-2627$ (1982), and authorizes the Secretary, any affected electric utihity, or any electric consumer of an affected electric utility, to intervene as a matter of right in any ratemaking proceeding conducted by a state regulatory authority. 16 U.S.C. $\$ \$$ 2631-2634 (1982). Title II authorizes the FERC to order interconnection between small power producers, cogenerators and other utilities, 16 U.S.C. $\$ 824 \mathrm{i}$ (1982), order "wheeling" between utihities, 16 U.S.C. $\$ 824 j$ (1982), and exeinpt electric utilities from any provision of state law, state rule, or regulation that prevents voluntary coordination of electric utilities where such voluntary coordination is designed to acquire economic utilization of facilities and resources in any area. 16 U.S.C. \& 824a(1) (1982). Title II further requires the FERC to promulgate rules designed to ensure continuity of service to customers of public utilities, 16 U.S.C. $\S 824 \mathrm{a}(9)(1982)$, and to produce electric utility reliability standards, 16 U.S.C. $\$ 824 a(2)$ (1982). The Act also created or revised federal regulatory authority over natural gas utilities, 16 U.S.C. $\$ 2701$ (1982), and crude oil transportation systeıns. 43 U.S.C. $\$ \S 2005-2012$ (Supp. III 1979). For an in-depth analysis of 
however, went "one step beyond" 53 the surface mining legislation considered in Virginia Surface Mining in that the public utilities law provided procedural rules which the states were to follow in considering the federal proposals. ${ }^{54}$

Justice Blackmun, writing for the majority, lield that, because Congress could have preeinpted the field, at least in thc area of private rather than state activity, "PURPA should not be invalid simply because, out of deference to state authority, Congress adopted a less intrusive scheme . . . ."55 Justice Blackmun also noted that no state was compelled to act; states could avoid the impositions of PURPA inerely by ceasing to regulate public utilities. ${ }^{56}$ Because the state voluntarily took up public utilities regulation, there was, in the Court's view, no rooun to assert a tenth amendment claim. ${ }^{57}$

the Act, see generally Note, The Constitutionality and Effectiveness of the Electric Utility Provisions of the Public Utility Regulatory Policies Act of 1978, 47 GEO. WASH. L. REv. 787 (1979).

53. FERC v. Mississippi, 456 U.S. at 764.

54. The agency must prepare its regulation after public notice and a liearing, and its final determinations must be in writing, based upon evidence presented at the hearing and available to the public, 16 U.S.C. $\$ \S 111,2621$ (b)-(c) (1982). To avoid placing a financial burden on the states, the Secretary of Energy is authorized to make grants to state regulatory authorities to assist them in carrying out the procedural provisions. 42 U.S.C. \& 6807 (Supp. III 1979).

55. FERC v. Mississippi, 456 U.S. at 765 . The motives of Congress, however, inay not be as pristine as the Court suggests. By einploying state institutions to advance federal policy, Congress may be fashioming a compronise where majority support for total preemption in the field is lacking.

56. Id. at $765-66$.

57. Id. at 769-70. Justice $\mathrm{O}^{\prime}$ Connor, writing in dissent, criticized the majority's einphasis on a state's "choice" in determining tenth amendinent violations. She asserted that "under the Court's analysis . . . National League of Cities v. Usery . . would have been wrongly decided, because the States could have avoided the Fair Labor Standards Act by 'choosing' to fire all employees subject to that Act, and to close those branches of state govcrnment." Id. at 781-82 (O'Connor, J., dissenting) (footnote omitted). This conclusion, however, is not supported by the Court's analysis. The "choice" that the majority has found permissible is created when the federal government indirectly coerces the state by threatening preemption in a field constitutionally preemptible, in an effort to affect certain state functions that Congress could not reach through direct legislation because of the tenth ainendment. Justice O'Connor's suggestion that, under the majority's analysis, the existence of a state choice rescues even direct legislation affectimg protected state functions from tenth amendment infringement goes well beyond Justice Blackmun's assertion.

The decision conflicted with the approach of the Court in Usery, Justice O'Connor maintained:

The Court, however, does not explain why our National League of Cities opinion did not consider compliance with the Fair Labor Standards Act in fields such as "licensing of occupations and businesses, . . . preservation of environmental quality, . . . [and] protection of the public against fraud and sharp practice," a "conditio[n] on the State's regulation of private conduct in a pre-emptible area." In that case, Congress had required the States to pay their einployees specified amounts if they wished to continue regulating a variety of pre-enptible fields.

Id., at 782 n.9 (O'Connor J., dissenting) (quoting Brief for Appellant at 16, National League of Cities v. Usery, 426 U.S. 833 (1976)). 
Taken at face value, the Court's assertion that the existence of state choice insulated federal legislation froin tenth amendment attack is not satisfactory. The Court recognized that the ability of a state legislative body to consider and promulgate regulations of its own choos$\mathrm{mg}$ is a central element of state sovereignty. ${ }^{58}$ Furtherinore, it acknowledged that a state would probably find it difficult to abandon its regulatory role..$^{59}$ The Court conceded that, as a practical matter, the state had been forced to acquiesce in the federal government's infringement of its sovereignty. The Court, however, denied that such practical necessities have any constitutional relevance: "Thus it cannot be constitutionally determinative that the federal regulation is likely to move the States to act in a given way, or even to 'coerc[e] the States' into assuming a regulatory role by affecting their 'freedom to make decisions in areas of integral state functions." "60

This "consent" approach is even more troubling because the Court did not define the required nexus between the field which is preempted and the acts which Congress desires the states to perform. In FERC $v$. Mississippi, Congress preenpted the field that it sought to regulate. But FERC v. Mississippi does not limit the scope of its holding to subjects where Congress could preempt the field. For instance, under a literal interpretation of the holding, Congress could have conditioned nonpreemption of the regulatory field of public utilities upon a state's enactimg a statute bringing police and firemen under the FLSA. It would have preempted a field over which it had authority to do so and

The difficulty with this view is that Usery is not parallel to FERC v. Mississippi. In Usery, the protected state function was not the employer-employee relationship as such, but rather only rclationships in certam essential state functions. See National League of Cities v. Marshall, $429 \mathrm{~F}$. Supp. 703, 704-06 (D.D.C. 1977). It could be assumed that where the federal governinent could constitutionally preempt a field previously regulated by the state, such a state function could not be essential and thus the employer-employee relationship in that field would not be subject to the Usery holding. If this is so, then Justice O'Connor's use of Usery should not be viewed as support for the proposition that before FERC v. Mississippi the Court would have held impermissible a threat by Congress of federal preemption in an attempt to affect a state function protected by the tenth amendment.

Although not inconsistent with the holding of Usery, FERC v. Mississippi does appear to intrude upon the spirit of the doctrine. As the example in the text seeks to illustrate, if taken literally and without quahification, the majority analysis, while upholding the Usery decision, directs Congress to a back door through which all of the protection bestowed upon the states by $U_{\text {sery }}$ can be removed while leaving the decision intact. This procedure would parallel the Court's analysis of the spending power, in which the Court has held that the power was independent and not restricted by Congess's other enumerated powers and could therefore be used to coerce states to perforn in ways that Congress could not directly legislate. See United States v. Butler, 297 U.S. 1, 66 (1966).

58. FERC v. Mississippi, 456 U.S. at 761.

59. Id. at 766 .

60. Id. (quoting Virginia Surfaee Mining, 452 U.S. at 289). 
it would have given the states the choice whether to take action. In short, the consent theory, if taken to its logical extreme, would create a substantial gap in the Usery rationale.

That Justice Blackmun, the author of FERC v. Mississippi, provided the crucial fifth vote in the Usery decision suggests that FERC $v$. Mississippi should not be read as abandoning the concerns for state sovereignty that led to the decision in Usery. Instead, the "consent" theory should be understood to apply within the parameters of Justice Blackmun's "balancing approach" in Usery. That is, the consent approach is more likely to be applied when the federal interest is strong and the state interest weak than when the state interest is strong and the federal interest weak. In FERC v. Mississippi, for instance, the Court viewed the problein addressed by PURPA as an important federal concern that required uniform behavior on the part of all energy producers. ${ }^{61}$ This important federal concern outweighed the state's interest im regulating private energy producers and avoiding the procedural restraints imposed by PURPA. Thus, the Court developed the consent approach to avoid potential tentli-amendment problems and intended it to apply only when the federal government has a strong interest in regulating particular fields.

\section{EEOC $V$. Wyoming: The Constitutional Relevance of THE DEgReE of IMPAIRMENT OF STATE FunCtions}

Underlying Virginia Surface Mining and FERC v. Mississippi were concerns about the potential of the tenth amendment being used as vehicle to uphold conflicting state laws in areas where Congress, in the Court's view, had a legitimate right to regulate. In both cases, the Court implicitly weighed federal and state interests. This analysis differed substantially from that suggested by Justice Rehnquist in Usery ${ }^{62}$ and resembled the balancing approach outhined by Justice Blackmun in his Usery concurring opimion. ${ }^{63}$ The decision in EEOC $v$. Wyoming ${ }^{64}$ brought the Court yet closer to Justice Blackmun's 'balancing approach." The Court not only compared the federal and state interests, but also considered the degree to which federal legislation infringed on state sovereignty, a characteristic that Justice Rehnquist's approach in Usery dismissed as irrelevant.

\footnotetext{
61. See FERC v. Mississippi, 456 U.S. at 745.

62. See supra notes $28-30$ and accompanying text.

63. See supra notes $31-32$ and accompanying text.

64. 103 S. Ct. 1054 (1983).
} 


\section{A. The Court's Decision.}

The case arose when the Equal Employment Opportunity Commission (EEOC) brought suit against the State of Wyoming for violation of the Age Discrimination in Employment Act of 1967 (ADEA). ${ }^{65}$ Under the ADEA, it is unlawful for an employer to discriminate against an employee on the basis of age.66 In 1974, Congress had amended the Act to extend the definition of "einployer" to include state and local governments. ${ }^{67}$ The Wyoming statute in question provided a mandatory retirement age for all game and fish wardens. ${ }^{68}$ Attorneys for the state argued that the 1974 anendments extending the Act to state employees violated the tenth amendment. They claimed that a state's relationship with its park and recreation employees was an es-

65. 29 U.S.C. § 621-624 (1982). The Wyoming Game and Fish Department, pursuant to a state statute, had forced a District Game Division supervisor to retire. The supervisor filed a complaint with the EEOC claiming that the state had violated the ADEA. The Commission then filed suit in the District Court for the District of Wyoming seeking declaratory and injunctive relief, back pay, and liquidated damages. The district court, upon defendant's motion, dismissed the suit holding that the ADEA violated the tenth-amendment doctrine as enunciated in Usery' to the extent the statute applied to state game wardens and law enforcement officials. See EEOC v. Wyoming, $103 \mathrm{~S}$. Ct. at 1059-60.

66. Congressional concern with arbitrary age discrimination throughout the 1950's and early 1960's culminated in the Age Discrimination in Employment Act of 1967. The Act prohibits various forms of age discrimimation in employment sucl as the discharge of employees on the basis of age. 29 U.S.C. $\S 623$ (a) (1982). This protection was himited to workers between the ages of 40 and 65,29 U.S.C. $\$ 631$ (1982), until Congress expanded the upper boundary of this classification to the age of 70. Age Discrimination in Employment Act Amendments of 1978, Pub. L. No. 95-256, § 3, 92 Stat. 189 (codified 29 U.S.C. $\$ 631$ (1982)). In recognition of the fact that criteria related to age are justified in some circumstances, the Act provides that "where age is a bona fide occupational qualification reasonably necessary to the normal operation of the particular business," its use in employment decision is not unlawful. 29 U.S.C. $\$ 623$ (f)(1) (1982).

67. 29 U.S.C. $\& 630(b)$ (1982).

68. The Wyoming State Highway Patrol and Game and Fish Warden Retirement Act, WYo. STAT. § 31-3-107 (I977) provides that:

a) Any employee who has four (4) or more years of service to his credit shall be eligible to receive a retirement allowance under this act when lie attains the age of fifty (50).

b) During the period from July I, 1973, through June 30,1977, an employee who lias twenty-five (25) or more years of service may retire when such employee reaclies the age of sixty (60) years, at the discretion of the employer, and receive a benefit as described in [\$ 31-3-110] of the statutes. An employee may retire at an earlier age, at the discretion of the employer, provided the benefit payable at sucl earlier age shall be the actuarially determined equivalent value to the benefit commencing at age sixty (60). After June 30, 1977, an employee with twenty-five (25) or more years of service may elect to retire and receive a benefit upon attaining the age of fifty-five (55) years as described in $[\$ 31.3-110]$ of the statutes, or at an earler age on an actuarially determined equivalent basis.

c) An employee may contimue in service on a year-to-year basis after age sixty (60) until June 30,1977, and thereafter age fifty-five (55), with the approval of employer and under conditions as the employer may proscribe.

d) Any employee in service who has attained the age of sixty-five (65) years, shall be retired no later than the last day of the calendar month in which lis 65 th birthday occurs. 
sential state function with which Congress could not constitutionally interfere.

Justice Brennan wrote the inajority opinion for the Court, holding the federal legislation constitutional as applied to the state. ${ }^{69}$ The Court applied the three-part test that it liad announced in Virginia Surface Mining. 1t found that the first requirement, that the statute regulate the states as states, was "plainly met."70 The Court, held, however, that the third requirement was not satisfied; the ADEA did not directly impair the states's ability to structure integral operations in areas of traditional governmental functions. ${ }^{71}$ The Court thus found it unnecessary to resolve the more difficult question of whether the federal stat-

69. The Court could have avoided the Usery doctrine altogether by finding that the ADEA was a valid exercise of congressional power under the fourteenth amendment. See U.S. ConsT. amend. XIV, § 5. As the Court proclaimed in City of Rome v. United States, 446 U.S. 156, 179 (1980), Congress is not restricted by the tenth amendment constraints that circumscribe the exercise of the cominerce clause power when properly exercising its power under $\S 5$ of the fourteenth amendment. Such an interpretation of the ADEA would hardly have been unique. See, e.g., EEOC v. County of Calumet, 686 F.2d 1249, 1251-52 (7th Cir. 1982); EEOC v. Elrod, 674 F.2d 601, 609-10 (7th Cir. 1982); Arritt v. Grisell, 567 F.2d 1267, 1269-70 (4th Cir. 1977); Coffin v. South Carolina Department of Social Services, 562 F. Supp. 579, 582 (D.S.C. 1983); Adams v. James, 526 F. Supp. 80, 84 (M.D. Ala. 1981); EEOC v. Peimsylvania Liquor Control Bd., 503 F. Supp. 1051, 1052-53 (M.D. Pa. 1980). The issue of whether the ADEA was enacted under $\S 5$ of the fourteenth amendment was argued by both parties. Brief for Appellant at 21-37, EEOC v. Wyoming, 103 S. Ct. 1054 (1983); Brief for Appellee at 20-29, EEOC v. Wyoming, 103 S. Ct. 1054 (1983). The issue was also sharply debated at oral argument. Transcript at 11-22, 34-43.

The Court's avoidance of this approach might be explained by reference to certain exceptions in ADEA's application to the federal government. As Chief Justice Burger asserted, EEOC, 103 S. Ct. at 1075 (Burger, C.J., dissenting), federal law enforcement officials are exempt froin the Act. See 5 U.S.C. $\$ 8335(\mathrm{~b})$ (1982):

A law enforcement officer or a firefighter who is otherwise eligible for immediate retirement . . . shall be separated from the service on the last day of the month in which he becomes 55 years of age or completes 20 years of service if then over the that age. The head of the agency, when in his judgment the public interest so requires, inay exeinpt such an employee from automatic separation under this subsection until that einployee becomes 60 years of age.

This passage resembles WYO. STAT. ANN. § 31-3-107 (1977).

In its examination of the scope of congressional power under $\S 5$ of the fourteenth ainendment, in Katzenbach v. Morgan, 384 U.S. 641 (1966), and Oregon v. Mitchell, 400 U.S. 112 (1970), the Court appeared to hold that Congress can expand the coverage of the amendment beyond the limits set by judicial interpretation, subject only to the requirennent that Congress must rationally conclude that a given set of actions violated rights guaranteed by its broader definition of the fourteenth amendment. See L. TRIBE, AMERICAN ConstituTIONAL LAw 261-72 (1977). See also EEOC v. Wyoming, 103 S. Ct. 1068, 1073-74. (Burger, C.J., dissenting). If the Court were to hold that Congress enacted the ADEA pursuant to $\S 5$, the Court would be faced with the issue of whether an act of a state can be held to violate the fourteenth amendment at the same time that an identical act of the federal government is constitutionally permissible. It inay well be that this looming constitutional double standard persuaded the Court to avoid any recourse to $\S 5$ and to deal solely with the commerce-clause power.

70. EEOC v. Wyoining, $103 \mathrm{~S}$. Ct. at 1061.

71. Id. at 1062 . 
ute addressed attributes of state sovereignty. ${ }^{72}$

In arriving at its conclusion, the Court reiterated that management of state parks is a traditional state function. It emphasized that the purpose of the Usery doctrine was to "protect States from federal intrusions that might threaten their 'separate and independent existence.' "73 It reasoned, however, that the determination of direct inpairnent of essential functions must depend "on considerations of degree,"74 and undertook to determine what degree of infringment had actually occurred. Justice Brennan noted that the enforcement of the ADEA would not prevent Wyoming froin achieving its articulated goal of " 'assuring the physical preparedness of Wyoming game wardens to perform their duties." "75 Wyoming, in the Court's view, was still free to assess physical preparedness through individual examinations. Further, the state could have apphed its rules for inandatory retirement without offending the ADEA if it could dennonstrate that age is a bona fide occupational qualification for park rangers. ${ }^{76}$ Therefore, the Court held that the ADEA did not intrude sufficiently into state affairs to render the legislation unconstitutional.

\section{B. An Examination of the Court's Analysis.}

EEOC v. Wyoming nowhere contams an exphicit rejection of Justice Rehnquist's approach in Usery. The decision implicitly suggests, however, that the Rehnquist test is no longer favored by a majority of the Court. Justice Brennan's stateinent that tenth amendment violations depend on the degree of infringenent reflects the Court's acceptance of a inethod for analysis which Justice Rehnquist had rejected in Usery. In Usery, the Court had been concerned with whether any infringement had occurred; 77 the degree was constitutionally irrelevant.

72. Id. at 1061. The Court, while recognizing that a state's employment relationship with its workers can often be an exercise of its sovereign core functions, as was the case in Usery, emphasized that it should "not be understood to suggest that every state employment decision aimed simply at advancing a generalized interest in efficient management-even the efficient management of iraditional state functions - should be considered to be 'an exercise of an undoubted attribute of state sovereignty.'" Id. at $1061 \mathrm{n} .11$ (emphasis added). This language, although not directly bearing on the case, suggests that the Court was intent on tightening the loosely defined parameters of Usery, a point further illustrated by the ultimate holding in the case. See infra notes 77-89 and accompanying text.

73. EEOC v. Wyoming, $103 \mathrm{~S}$. Ct. at 1061.

74. $I d$.

75. Id. (quoting Brief of Appellees at 18).

76. $I d$.

77. The court even went so far as to search for infringements of social policy:

The state might wish to employ persons with little or no training, or those who wish to work on a casual basis, or those who for some other reason do not possess minimum employment requirements, and pay them less than the federally prescribed minimum 
Justice Rehnquist's approach was more deferential to state concerns for autonomy. His test was extraordinarily receptive to the states's concerns and the Usery majority seemed willing to accept, at face value, the states's claims that federal legislation would adversely affect essential state functions. ${ }^{78}$ For instance, the Usery Court accepted the "well pleaded allegations" of the state's as accurate" despite claims by the Secretary of Labor that the state cost allegations were grossly exaggerated. ${ }^{80}$ The EEOC $v$. Wyoming Court was less deferential to state claims. It rigorously examined all of the state's allegations of infringement to deterunine their accuracy and whether the alleged infringements were of both the degree and the quality to support the state's claim of a tenth amendment violation.

In EEOC v. Wyoming the Court seemed to reject the notion that fiscal impact would always justify a finding that the federal legislation impermissibly infringed on legitimate state functions. For instance, in holding that Wyoming could achieve its goals by providing individual physical examinations to employees over the age of fifty-five, ${ }^{81}$ the Court refused to consider the cost increase to the state of providing such examinations. The Court's rationale that the ADEA would not affect the state at all if the state could prove that age was a bona fide occupational qualification for the job in question ignored the legal costs that the state would have to bear in defending lawsuits challenging age as such a qualification. ${ }^{82}$ The Court also dismissed the argument that, because older workers with seniority are paid more than younger employees, the apphication of the ADEA will increase the State's expenditures, noting that

these increased costs, even if they were not largely speculative in their own right, might very well be outweighed by a number of other factors: Those saine older workers, as long as they remain employed, will not have to be paid any pension benefits at all, and will continue to contribute to the pension fund. And, when they do retire, they will likely, as an actuarial matter, receive benefits for fewer years than workers who retire early. ${ }^{83}$

wage. It may wish to offer part-time or summer employment to teenagers at a figure less than the mimimum wage....

Usery, 426 U.S. at 848 (emphasis added).

78. Id. at 846 .

79. Id.

80. Brief for Appellee at 44-53, Usery, 426 U.S. 833 (1976).

81. EEOC v. Wyoming, $103 \mathrm{~S}$. Ct. at 1062.

82. Id. at 1072 n.5 (Burger, C.J., dissentimg).

83. Id. at 1063 (emphasis added). Wyoming further argued that the costs of state health and other benefit plans would increase if extended to older workers. The Court, however, disposed of this point by noting that 29 U.S.C. $\S 623(f)(2)$ (1982) provides that the ADEA shall not be inter- 
Thus, although the Court in Usery was satisfied with the possibility of actual harmful fiscal impact, the Court in EEOC v. Wyoming seemed unimpressed by anything other than a showing of certain and substantial infringement.

That Justice Brennan deviated from the Rehnquist approach in Usery is further illustrated by his use of the phrase "particularized assessments of actual impact." ${ }_{4}$ The Usery Court had used the phrase to emphasize that the practical effects of the FLSA were not constitutionally relevant. ${ }^{85}$ Justice Brennan, however, asserted in EEOC v. Wyoming that:

The test of such financial effect as drawn in National League of Cities does not depend, however, on "particularized assessments of actual impact," which may vary from State to State and time to time, but on a more generalized inquiry, essentially legal rather than factual, into the direct and obvious effect of the federal legislation on the ability of the States to allocate their resources. ${ }^{86}$

In EEOC v. Wyoming, the Court used the phrase not to deemphasize actual inpact, but to introduce a broader investigation. The mere claim by one state of an increased financial burden is no longer sufficient to render federal legislation unconstitutional under the tenth amendment. Now a state must convince the Court that the law in question would substantially alter an essential state function. ${ }^{87}$

According to Usery, as imterpreted by Chief Justice Burger's dissent in $E E O C$ v. Wyoming, states exercise their sovereign powers when they decide whom to employ, as much as when they exercise control over wages paid to their employees. ${ }^{88}$ In addition, under Usery, law enforcement officials are considered essential to the independent existence of the states. ${ }^{89}$ Because the ADEA interferes with a state's abihty to decide whom to employ for law enforcement positions, it appeared to violate the tenth amendment as construed in Usery. The Court's decision to uphold the ADEA in EEOC $v$. Wyoming, despite the Usery

preted to require that health and other benefits received by older workers be identical to those of younger employees. EEOC v. Wyoming, $103 \mathrm{~S}$. Ct. at 1063.

In order to take advantage of the provision, however, Wyoming would be required to enact new laws and create new regulations to decrease its insurance coverage of older workers. Chief Justice Burger mamtamed in disseut that "[d]rafting and enacting these new laws is a burden Cougress has no power to impose on the States." Id. at 1071 (Burger, C.J., dissenting).

84. EEOC v. Wyoming, $103 \mathrm{~S}$. Ct. at 1063.

85. Usery, 426 U.S. at 851.

86. EEOC v. Wyoming, $103 \mathrm{~S}$. Ct. at 1063.

87. The Court, upon making this statement, proceeded to investigate whether the ADEA, by increasing the number of elderly employees, would place a burden upon the state's fiscal resources, and concluded that it would not. Id.

88. Id. at 1069 (Burger, C.J., disseuting).

89. Usery, 426 U.S. at 851 . 
holding, suggests that a majority of the Court now accept Justice Blackmun's balancing approach in which the degree of the infringement of state functions is constitutionally relevant.

\section{CONCLUSION}

The Usery doctrine represented an important step toward state freedom from federal regulation. But its potentially revolutionary approach suffered froin two weaknesses: the difficulty of applying the holding in light of ambiguities such as "essential state functions" and "state sovereignty," and the problem of determining the weight to be accorded the majority opinion in view of Justice Blackmun's terse but significant concurring opinion. In subsequent cases, the Court struggled with the latter difficulty and, in Virginia Surface Mining and FERC v. Mississippi, einbraced the element of Justice Blackmun's balancing test that focuses on the relative strength of the federal and state interests. The Court's opimon in EEOC v. Wyoming represents a continuation of the Court's acceptance of this balancing approach and establishes the constitutional relevance of the degree of infringement of the state interests.

It is teinpting to read EEOC v. Wyoming as implicitly overruling Usery..${ }^{90}$ The temptation is increased by the fact that Justice Brennan, the chief dissenter in Usery, ${ }^{91}$ wrote the opimion in EEOC $v$. Wyoming. The Usery doctrine, however, has continued vitality. The emergence of the balancing test, it is true, will have the effect of narrowing the Usery doctrine in that fewer infringenents of essential state functions will now be found to violate the tenth amendment. The balancing test, however, does preserve the heart of the Usery doctrine-that the tenth amendment restricts Congress's enuinerated powers. The current composition of the Court further suggests that any requiem for the Usery doctrine is premature. The Court in 1983 is as polarized on the tenth amendment issue as it was in 1976. The Usery decision had the support of Chief Justice Burger and Justices Rehnquist, Powell and Stewart-with Justice Blackmun providimg the crucial fifth vote. Dissentimg were Justices Brennan, White, Marshall, and Stevens. In botll FERC v. Mississippi and EEOC v. Wyoming, the alliances were similar, ${ }^{92}$ with but one sigmificant difference-Justice Blackmun. The cases following

90. See N.Y. Times, March 3, 1983, at A19, col. 1.

91. Usery, 426 U.S. at $856-80$.

92. Of course, Justice O'Connor replaced Justice Stewart. In addition, both Justice Powell and Justice O'Connor separately concurred in part and dissented in part in FERC v. Mississippi, 456 U.S. at 771-75 (Powell, J., concurring in part and dissenting in part); id. at 775-97 (O'Connor, $\mathrm{J}$. , concurrimg in part and dissentiug in part). 
Usery provide no clear indication that Justice Blackmun has altered his view towards tenth-amendment issues. Thus, for the time being, the resolution of tenth-amendment claims will depend on Justice Blacknun.

Vincent Daniel Palumbo 